Reassessing Egalitarianism 
Also by Jeremy Moss

CLIMATE CHANGE AND SOCIAL JUSTICE (editor)

RISK AND RESPONSIBILITY (edited with Greg Marston and John Quiggin) 


\section{Reassessing Egalitarianism}

Jeremy Moss

The Social Justice Initiative, University of Melbourne, Australia 

publication may be made without written permission.

No portion of this publication may be reproduced, copied or transmitted save with written permission or in accordance with the provisions of the Copyright, Designs and Patents Act 1988, or under the terms of any licence permitting limited copying issued by the Copyright Licensing Agency, Saffron House, 6-10 Kirby Street, London EC1N 8TS.

Any person who does any unauthorized act in relation to this publication may be liable to criminal prosecution and civil claims for damages.

The author has asserted his right to be identified as the author of this work in accordance with the Copyright, Designs and Patents Act 1988.

First published 2014 by PALGRAVE MACMILLAN

Palgrave Macmillan in the UK is an imprint of Macmillan Publishers Limited, registered in England, company number 785998, of Houndmills, Basingstoke, Hampshire RG21 6XS.

Palgrave Macmillan in the US is a division of St Martin's Press LLC, 175 Fifth Avenue, New York, NY 10010.

Palgrave Macmillan is the global academic imprint of the above companies and has companies and representatives throughout the world.

Palgrave ${ }^{\circledR}$ and Macmillan ${ }^{\circledR}$ are registered trademarks in the United States, the United Kingdom, Europe and other countries

ISBN 978-1-349-48144-6

ISBN 978-1-137-38598-7 (eBook)

DOI $10.1057 / 9781137385987$

This book is printed on paper suitable for recycling and made from fully managed and sustained forest sources. Logging, pulping and manufacturing processes are expected to conform to the environmental regulations of the country of origin.

A catalogue record for this book is available from the British Library.

A catalog record for this book is available from the Library of Congress. 


\section{Contents}

Introduction $\quad \mathbf{1}$

The value of equality $\quad 3$

Equality of what? $\quad 4$

$\begin{array}{ll}\text { Equality and responsibility } & 7\end{array}$

Global egalitarianism $\quad 9$

$\begin{array}{ll}\text { Scope and focus } & 14\end{array}$

1 The Value of Equality 17

$\begin{array}{lll}1.1 & \text { Introduction } & 17\end{array}$

The importance of equality 19

1.2 Equality as intrinsically valuable 24

$\begin{array}{lll}1.3 & \text { Equality and sufficiency } & 26\end{array}$

$\begin{array}{ll}\text { Scarcity } & 27\end{array}$

Thresholds $\quad 28$

1.4 Prioritarianism $\quad 29$

Leveling down 30

1.5 Egalitarian responses $\quad 33$

Pluralism $\quad 33$

Fairness $\quad 34$

$\begin{array}{lll}1.6 & \text { Valuing equality } & 38\end{array}$

$\begin{array}{lll}1.7 \text { Conclusion } & 39\end{array}$

2 Equality of What? $\quad 41$

2.1 Introduction 41

2.2 Equality of welfare 45

$\begin{array}{ll}\text { Actual preferences } & 47\end{array}$

Success theories $\quad 49$

Responses $\quad 51$

2.3 Equality of resources $\quad 54$

Rawls and primary goods $\quad 55$

Criticisms of Rawls's account of primary goods 56

2.4 Dworkin: auctioning resources 58

Insurance and endowment insensitivity: luck and handicaps 60

Dworkin's equality of resources: preferences and the market 
Dworkin on the market and the role of preferences 63

2.5 Capabilities 65

Sen and capabilities $\quad 65$

$\begin{array}{ll}\text { Nussbaum and capabilities } & 69\end{array}$

2.6 Assessment of the capability approach 71

Freedom $\quad 71$

Selection and weighting $\quad 74$

Hard cases, heterogeneity, and disrespect $\quad 77$

$\begin{array}{ll}2.7 \text { Conclusion } & 79\end{array}$

3 Egalitarianism and Responsibility $\quad 85$

3.1 Introduction $\quad 85$

Different kinds of responsibilities $\quad 88$

Two roles for equality: Rawls and the luck egalitarians $\quad 90$

$\begin{array}{ll}3.2 \text { Motivating luck egalitarianism } & 91\end{array}$

The harshness objection and lack of respect $\quad 92$

Limiting the role of chance and choice 93

$\begin{array}{ll}3.3 \text { Relational egalitarianism } & 96\end{array}$

Equality as equal standing $\quad 96$

3.4 Luck egalitarian responses 98

3.5 Conclusion: assessing the debate 103

4 Global Egalitarianism 108

4.1 Introduction 108

4.2 Justice as association: the basic structure 111

4.3 Assessing the cooperation/reciprocity argument 113

Reciprocity 113

Pervasive impact $\quad 115$

Coercion 115

4.4 Moral personality 118

Moral persons $\quad 119$

4.5 Equality of natural resources 123

4.6 Equality and the carbon budget $\quad 129$

The atmosphere and equal shares 132

Assessing the equal per capita approach $\quad 134$

4.7 Conclusion 136

Conclusion: Assessing the Prospects for Egalitarianism 139

Notes $\quad 144$

Bibliography 165

Index 175 


\section{Acknowledgements}

This book has benefited from numerous discussions and opportunities to present the material. For discussing parts of the book, I thank audiences at the universities of ANU, Beijing, Graz, Hong Kong, Lisbon, Oxford, Macquarie, McGill, Melbourne, Queensland, Sydney, UNESCO, and Wellington. The book was written in part while I visited the universities of Oxford and McGill, and they provided very congenial research environments. I particularly thank the participants of the Crash Course on Egalitarianism at Université catholique de Louvain in 2012 and Axel Gosseries for organizing it, as well as the participants of the Just Equality Workshop: Dan Halliday, Sanyar Sagal, Greg Bognar, Axel Gosseries, and Robert Young. I would also like to thank Graham Brown, Director of the Nossal Institute of Global Health, for his support during the research for this book. Some of the many people who have discussed parts of the book with me are Dave Archard, Dick Arneson, John Baker, Paula Casal, Tony Coady, Simon Caney, Garrett Cullity, Iwao Hirose, Simon Keller, Uwe Steinhoff, Adam Swift, Andrew Williams, and Jo Wolff. I thank them for their input. I also particularly thank Robert Young for many conversations on the topics collected in this book; they have been instrumental in making it a better work.

Earlier versions of some of the material have appeared in print as follows. I thank the publishers for permission to republish.

Moss, Jeremy. "Egalitarianism and the Value of Equality." Journal of Ethics and Social Philosophy, 2 (2009): 1-6.

Moss, Jeremy, "Against Fairness." Journal of Value Inquiry, 41 (2007): 309-324.

The book has also had the crucial support of a number of grants from the Australian Research Council - they enabled me to have time off for research and travel to other universities - in particular an ARC Future Fellowship and a Discovery grant, Reassessing Egalitarianism. I thank the Council for its generous support. 